УДК 633.35

\title{
ПРОДУКТИВНОСТЬ ЧИНЫ ПОСЕВНОЙ (LATHYRUS SATIVUS L.) В УСЛОВИЯХ СУХОСТЕПНОЙ ЗОНЫ СЕВЕРНОГО КАЗАХСТАНА
}

\author{
Турбекова Арысгуль Сапаралиевна \\ к.с.-х.н., ассоциированный профессор КазАТУ \\ НАО «Казахский агротехнический университет» \\ Ошергина Ирина Петровна \\ заведующий отделом \\ Тен Евгений Алексеевич \\ заведующий ларораторией \\ ТОО «НПЦ зернового хозяйства \\ им. А.И. Бараева»
}

Аннотация: Проведено изучение 11 коллекционных сортообразцов чины посевной. По комплексу хозяйственно-ценных признаков выделились 5 сортообразцов, которые могут послужить ценными источниками исходного материала для селекции культуры чины посевной.

Ключевые слова: чина, коллекция, сортообразец, продуктивность, семена.

\section{Turbekova Arysgul Saparalievna Ochergina Irina Petrovna Ten Evgeny Alekseevich}

\begin{abstract}
The study of 11 collectible cultivars of the seed rank was carried out. According to the complex of economically valuable features, 5 cultivars have been identified, which can serve as valuable sources of source material for the selection of the seed rank culture.
\end{abstract}

Key words: Seed rank, collection, variety type, productivity, seeds.

Введение. Чина посевная (Lathyrus sativus L.) - это однолетнее бобовое растение, выращиваемое с древних времен во многих самых суровых агроэкологических условиях мира для употребления в пищу, а также на корм 
животным в виде зерна, сена и на зелёное удобрение [1, с 7]. Урожайность зерна и зелёной массы достигает 3,0 и 42,0 т/га соответственно [2, с.41]. Она характеризуется высоким содержанием белка - от 23,0 до 34,2\% [3, с 12], повышенной засухоустойчивостью, слабым поражением болезнями и вредителями, высокими кормовыми достоинствами и азотфиксирующей деятельностью [4, с 17].

Исследования направлены на выделение источников и доноров ценных признаков с целью вовлечения их в скрещивания и создания новых селекционных линий. Выделенные по хозяйственно-ценным признакам и свойствам образцы в дальнейшем будут использованы в качестве родительских форм при создании нового исходного материала методами гибридизации.

Материалы и методы исследований. Полевые опыты закладывались по чистому пару. Тип почв опытного участка - чернозёмы обыкновенные. Объектами исследования служили 11 образцов чины посевной, которые в коллекции представляют страну Народную Республикау Бангладеш, с кодовыми названиями: Ifla 1870; Ifla 2475; Ifla 2026; Ifla 2636; Ifla 2282; Ifla 2973; Ifla 2861; Ifla 2460; Ifla 2213; Ifla 2529; Ifla 2587 (рис.1).

Посев проведен в оптимальные сроки: 13 мая 2021 года, глубина заделки семян 4-5 см, расстояние между рядами 15 см, повторность 2-х кратная. Семенной материал высевался сеялкой ССФК-7 на делянках, в соответствии с методическими указаниями ВИР[5, с 145]. В период вегетации растений осуществились фенологические наблюдения. В период созревания перед уборкой делянок был проведён отбор структурного снопа с учетных площадок.
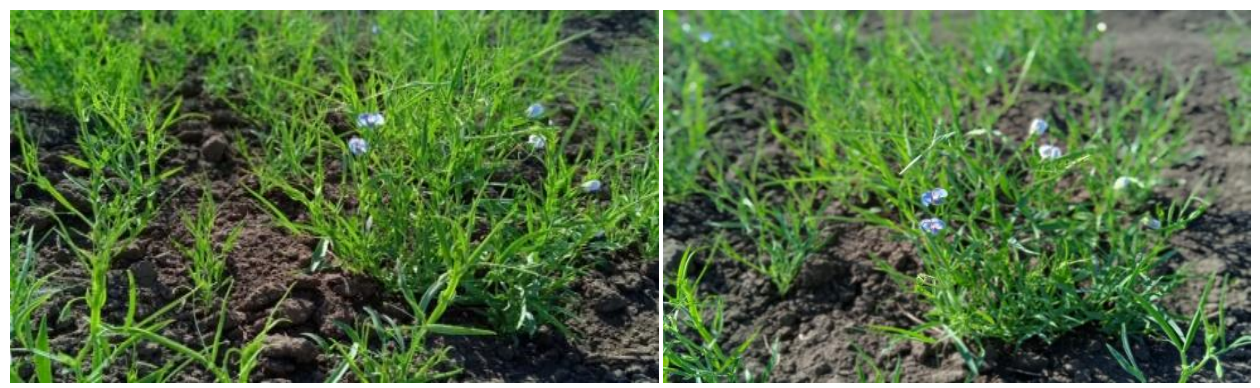

Рис. 1. Внешний вид сортообразцов чины посевной: Ifla 2529, Ifla 2460

Результаты. Продолжительность вегетационного периода от всходов до созревания у сортообразцов чины отмечается от 87 до 93 дней. Скороспелостью отличились сортообразцы Ifla 2026 и Ifla 2460 (87 дней), 
самым позднеспелыми оказался сортообразец Ifla 2973, у которого семена созрели только на 93 день (табл.1).

Таблица 1

\section{Продолжительность вегетационного периода}

и анализ продуктивности чины посевной, 2021

\begin{tabular}{|c|c|c|c|c|c|c|c|c|c|}
\hline \multirow[b]{2}{*}{ №п/ா } & \multirow{2}{*}{ 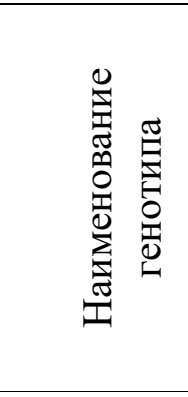 } & \multirow{2}{*}{ 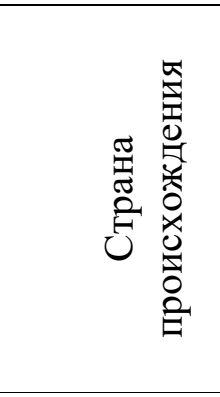 } & \multicolumn{2}{|c|}{$\begin{array}{c}\text { Вегетацион } \\
\text { ный период, } \\
\text { дни } \\
\end{array}$} & \multirow{2}{*}{ 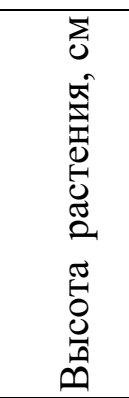 } & \multirow{2}{*}{ 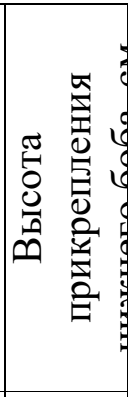 } & \multirow{2}{*}{ 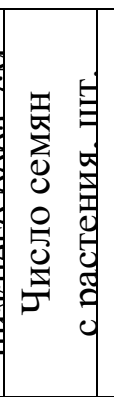 } & \multirow{2}{*}{ 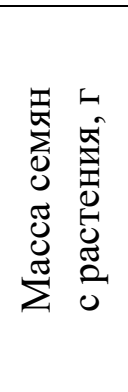 } & \multirow{2}{*}{ 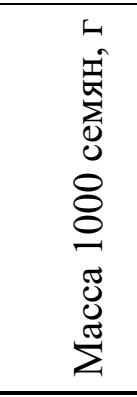 } \\
\hline & & & 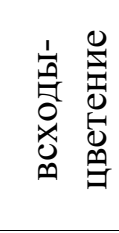 & 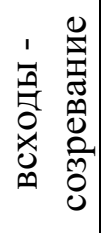 & & & & & \\
\hline 1. & Ifla 1870 & Bangladesh & 35 & 89 & 39,0 & 22,0 & $\begin{array}{c}29, \\
0 \\
\end{array}$ & 3,81 & 131,64 \\
\hline 2. & Ifla 2475 & Bangladesh & 35 & 89 & 40,0 & 20,0 & \begin{tabular}{|c}
24, \\
0
\end{tabular} & 4,72 & 195,29 \\
\hline 3. & Ifla 2026 & Bangladesh & 33 & 87 & 40,0 & 23,0 & $\begin{array}{c}17, \\
0\end{array}$ & 2,68 & 161,67 \\
\hline 4. & Ifla 2636 & Bangladesh & 38 & 92 & 43,0 & 24,0 & $\begin{array}{c}37, \\
0\end{array}$ & 4,89 & 145,67 \\
\hline 5. & Ifla 2282 & Bangladesh & 36 & 88 & 38,0 & 20,0 & $\begin{array}{c}17, \\
0\end{array}$ & 3,46 & 197,91 \\
\hline 6. & Ifla 2973 & Bangladesh & 37 & 93 & 52,0 & 24,0 & $\begin{array}{c}64, \\
0\end{array}$ & 6,34 & 83,54 \\
\hline 7. & Ifla 2861 & Bangladesh & 33 & 88 & 34 & 18 & $\begin{array}{c}35, \\
0\end{array}$ & 5,74 & 164,80 \\
\hline 8. & Ifla 2460 & Bangladesh & 32 & 87 & 32,0 & 19,0 & $\begin{array}{c}15, \\
0\end{array}$ & 1,93 & 125,12 \\
\hline 9. & Ifla 2213 & Bangladesh & 36 & 91 & 40,0 & 22,0 & \begin{tabular}{|c}
29, \\
0 \\
\end{tabular} & 5,12 & 173,73 \\
\hline 10. & Ifla 2529 & Bangladesh & 35 & 90 & 49,0 & 250 & $\begin{array}{c}58, \\
0\end{array}$ & 5,97 & 100,29 \\
\hline 11. & Ifla 2587 & Bangladesh & 36 & 91 & 52,0 & 23,0 & $\begin{array}{c}76, \\
0\end{array}$ & 7,24 & 95,96 \\
\hline
\end{tabular}

Bысота растений является важнейшим морфологическим признаком, характеризующим растение, так как от ее величины напрямую зависит степень полегания, которая в свою очередь влияет на семенную продуктивность и урожайность растений [6, с 19]. Самыми высокими оказались растения сортаобразцов как Ifla 2973 и Ifla 2587 достигшие в среднем по 52 см, когда самый низкий показатель по признаку высоты растения показали 
сортообразцы, как Ifla 2460 и Ifla 2861достигшие всего 32 и 34 см соответсвенно.

Воздушно-сухой вес растений определился в пределах от 3,80 и 13,44 г. Максимальный сухой вес у сортообраца Ifla 2587 и Ifla 2529 по 13,44 и 11,54 г. соответственно.

Высота прикрепления нижних бобов - один из основных признаков, определяющих технологичность культуры при механизированной уборке для целого ряда зернобобовых культур. Она измеряется как расстояние от поверхности почвы до первого продуктивного узла. Высота срезки на уборочных комбайнах чаще всего устанавливается на 12-15 см. Существуют механизмы, позволяющие более низкую срезку, но, учитывая неизбежную в производственных посевах неровность почвы, их применение нерационально и поэтому для производства необходимы сорта с более высокими расположением бобов [5, с 67]. По результатам наших исследований по данному хозяйственноценному признаку максимальные показатели наблюдались у таких сортообразцов, как Ifla 2973 и Ifla 2529, у них расстояния от поверхности почвы до первого продуктивного узла оказались 24 и 25 см соответсвенно, что на 9-10 см выше, чем необходимая высота.

Рассматривая особенности уровня проявления признаков число и масса семян с растения у сортообразцов чины посевной, можно отметить колебания: в среднем от 15 (Ifla 2460)до 76 (Ifla 2587) штук семян и от 1,93(Ifla 2460) до 7,24 (Ifla 2587) г семян с одного растения.

Macca 1000 семян - один из важных признаков, характеризующих урожайность и технологические свойства у сортов и форм чины посевной. Росийский ученый Г.Н. Васильев (1953) подразделяет чину посевную по массе 100 семян на три группы [6, с.22]: - крупносемянную (свыше 250г);среднесемянную (от 150 до 250 г);- мелкосемянную (от 50 до 150 г).

Сравнив средние значения массы 1000 семян за год изучения коллекции чины посевной, мы установили, что 6 сортообразов представлены по массе 1000 семян к мелкосемянной группе, т.е. от 83,5 до 145,67 г (Ifla 2973, Ifla 2587, Ifla 2529, Ifla 2460, Ifla 1870, Ifla 263 ) и среднесемянной группе, т.е. от161,6 до 197,9 г (Ifla 2026, Ifla 2861, Ifla 2213, Ifla 2475, Ifla 2282).

Выводы. По комплексу таких хозяйственно-ценных признаков, как скороспелость, сухой вес, высота растения, высота прикрепления нижнего боба, число и масса семян с одного растения и масса 1000 семян выделились сортообразцы Ifla 2529, Ifla 2282, Ifla 2475, Ifla 2213 и Ifla 2861. Они могут 
послужить ценным источником исходного материала для селекции культуры чины посевной в условиях сухостепной зоны Северного Казахстана.

\section{Список литературы}

1. Almeida N.F. et al. Allelic diversity in the transcriptomes of contrasting rust-infected genotypes of Lathyrus sativus, a lasting resource for smart breeding. BMC Plant Biol 14, 376 (2014). https://doi.org/10.1186/s12870-014-0376-2

2. Зыков Ю.Д. Чина посевная / Ю.Д. Зыков. А: Казсельхозгиз, 1963. 41 с.

3. Rizvi A.H, Sarker A., Dogra A. (2016) Enhancing grass pea (Lathyrus sativus L.) production in problematic soils of South Asia for nutritional security. Indian J Genet Plant Breed 76:583-592. https://doi.org/10.5958/0975-6906.2016. 00074.2

4. Choudhary A., Pandey P., Senthil-Kumar M. (2016) Tailored Responses to Simultaneous Drought Stress and Pathogen Infection in Plants. In: Hossain M., Wani S., Bhattacharjee S., Burritt D., Tran LS. (eds) Drought Stress Tolerance in Plants, Vol 1. Springer, , pp: 427-438 https://doi.org/10.1007/978-3-319-28899-4_18

5. Вишнякова М.А. и др. Коллекция мировых генетических ресурсов зернобобовых ВИР: пополнение, сохранение, изучение / - под ред. М.А. Вишняковой. - Санкт-Петербург: ВИР, 2018. -145 с.

6. Донская М.В. и др. Создание и оценка селекционного материала чины посевной в условиях северной части ЦЧР, Биология в сельском хозяйстве, I1,22, 2009, () ФГБОУ ВО Орловский ГАУ, 2019.

Исследования финансировались Комитетом Науки Министерства образования и науки Республики Казахстан «ИРН АР09561711 Интродукция генофонда чины для актуализации культуры в Северном Казахстане». 